\title{
Reflections from Women Doctoral Students Lives Regarding Gender Roles ${ }^{\#}$
}

\author{
Mediha Sarı, Buket Turhan Türkkan, Ece Yolcu \\ Çukurova University, Faculty of Education, Adana, Turkey
}

Corresponding author: Ece Yolcu, E-mail: duserece@gmail.com

\#This study was presented at $5^{\text {th }}$ Conference on Critical Education in Wroclaw, Poland (June 15-18, 2015).

\section{ARTICLE INFO}

Article history

Received: November 06, 2018

Accepted: January 18, 2019

Published: January 31, 2019

Volume: 7 Issue: 1

Conflicts of interest: None

Funding: None

\begin{abstract}
Engaging in business life actively with industrialization, modernism movements and making a significant improvement in getting higher education degrees, the women's getting postgraduate degrees -especially seen as a very challenging and demanding pathway by many people- has various effects on their social lives. The aim of this study was to analyze the interaction between doctoral process and women's gender roles in daily life. The design of the study was qualitative interview-based and to collect the data semi-structured interviews were conducted. Participants were chosen among the volunteer women doctoral students in Cukurova University. The data collected was analyzed with content analysis. The findings revealed there are many advantages and disadvantages reflected on the women doctoral students' lives through their doctorate regarding gender roles and they had a lot of difficulties through this process. They put forward recommendations related to various points such as providing equality of women and men and having support mechanisms in order to overcome these inequality related problems. Although they got both support and criticism regarding doing doctorate, women doctoral students have many reasons for doing doctorate which engage them into a devoted endeavor in a sense to get higher education and join more actively in business life.
\end{abstract}

Key words: Gender Roles, Women Doctoral Students, Doctoral Process

\section{INTRODUCTION}

To be a woman is a difficult phenomenon in both traditional and modern societies. Especially, being a working woman might be more challenging as it is making women's life more complex in many ways. When a woman aimed to have a career and develop herself her role becomes layered. The fundamental reason for this is not giving up the motherhood and housewifery roles attributed to married women regarding the traditional gender roles. In a patriarchal society, family or work environment where the man authority continues, it brings more challenges for a woman who wants on one hand to develop herself, make a career while on the other hand proceeds her duties regarding her house and motherhood and works at a place being paid, compared to men.

Many legal regulations have been made related to women's rights and equality of woman and man has been accepted under the law since the earlier years of republic in Turkey. However as emphasized by Arat (2000), it can be said that women in Turkey have been 'emancipated but unliberated'. Even if they gained many rights on paper, this unliberated situation that women face with through daily life becomes evident especially when women want to have career. The same situation is valid more or less for many countries around the world. Mostly working woman who are respon- sible for households at the same time feel the borders drawn by the society as they endeavor to make a career and get out of their gender roles traditionally assigned to them. When women start to work, demand equal rights with their male colleagues, compete on a level playing field with them and beyond all these, want to carry their careers to the highest level having graduate education, they come face to face with the traditional gender roles limiting them.

One of the starting points of women in desire of making career is generally to continue graduate education. In this process, having doctorate might be considered as an inevitable condition. However, the studies put forward that a woman's doing doctorate is more difficult than a man's (Elg \& Jonnergård, 2003; National Science Foundation [NSF], 2004; Thomas, Drake-Clark, Grasso \& Banta, 2014; Onwuegbuzie, Rosli, Ingram \& Frels, 2014). Elg and Jonnergård (2003) stated that a woman academic has to live up to more demands than a man in order to make a career. Women have to balance their lives in many ways as they have multiple roles as being wives, mother and professionals and this could create some problems making women leave their doctoral studies (Onwuegbuzie, Rosli, Ingram \& Frels, 2014). This case could be noticed looking at the rate of women in undergraduate and graduate education levels. According to the report prepared in 2015 by General Direc- 
torate on the Status of Women (GDSW) in Turkey, while the $45.8 \%$ of undergraduate students were women, $42.1 \%$ of the students at graduate level, doing masters or doctorate were women since 2013-2014 year. With regard to the data for 2013-2014 year, while 38.267 of 67.157 doctoral students were men, 28.890 of them were women (Turkish Statistical Institute [TSI], 2015). While the general rate is 43 $\%$ through academic personnel, it is observed that the rate of women academicians decreases with higher status. For instance, only in $12(6.8 \%)$ of 176 universities there is a woman rector (GDSW, 2015). These rates could be considered as an implication of women's having problems in attending and proceeding graduate education in Turkey. The situation is similar in other countries as well. Even though they are seen as the most developed countries with best educational systems in Finland, Sweden, there is again difference between women and men with doctoral degree. In Finland women having $\mathrm{PhD}$ degree are $0.9 \%$ while men having $\mathrm{PhD}$ are $1.2 \%$; in Sweden it is $0.9 \%$ for women and $1.5 \%$ for men (World Economic Forum [WEF], 2017). Also in other European countries, there are differences between women and men in terms of having a PhD degree such as in Germany 0.8 $\%$ for women and $1.8 \%$ for men; in France $0.6 \%$ for women and $1.0 \%$ for men (WEF, 2017).

As stated by Moyer, Salovey and Casey-Cannon (1999), women have to overcome many obstacles if they want to carry on with their academic careers. Although there are not any regulations against the equality of women and men through academic life, it has become an issue stressed in a lot of studies that women more frequently encounter with different problems in daily practices, at various levels (Fox, 2004; Kurtz-Costes, Helmke, \& Ülkü-Steiner 2006, Leonard, 2001; Margolis \& Romero, 1998; Raddon, 2002). Smith (1995) stated that women's doctorate process progress more slowly and they graduate later compared to men, though they are just as successful as men in the beginning stage and education process. According to Smith (1995), in addition to research funding and financial support, the individual and social factors effecting women's progress are gender stereotyping, social class, self-selection, role conflict and age discrimination. On the other hand, Fox (2004) stated that the women doctoral students face with many problems such as not being respected as men, being less comfortable within group works, not supported by advisors as much as men. They also feel the pressure of traditional gender expectations of social neighborhood and their personal and professional relationships play a strategic role within doctoral process (Wall, 2008).

There are not any regulations leading to an actual discrimination against women in higher education institutions in Turkey. Yet, the acceptance and prevalence of specific values and beliefs through dominant culture in the society, that is the dominant culture in universities makes it difficult for women to be successful in academic life. As Ergöl, Koç, Eroğlu and Taşkın (2012) indicate academician women face with the problem of balancing the work and family life in Turkey having a patriarchal structure in which the fundamental responsibilities of women are seen as house and family. The sexist approaches towards women have negative effects on their involvement in business life and having a career (Dinç Kahraman, 2010). In direction of these undesirable effects, women may feel that they cannot be successful as men are in business life or at managing status because of sexist stereotypes. As stated by İnand1 and Tunç (2012) and Duruoğlu (2007), they are mostly limited to house works and child care under the pressure of traditional approach.

Based on these findings, when we got through the literature in Turkey we found out that studies regarding the problems women encounter through academic life are very limited and there is no study analyzing the interaction between the gender roles within daily life and the doctoral process in detail. These all, form the need for such a study in order to make the point regarding the gender roles clear and also evaluate the situation in daily life and academic life based on gender.

\section{Purpose of the Study}

The aim of this study is to analyze the interaction between doctoral process and women's gender roles in daily life. In direction of this general purpose following research questions were guided the study:

According to the views of women doctoral students;

1. What are the mutual effects of being a woman and doing doctorate?

2. What are the reflections of neighborhood on their doing doctorate?

3. What are the recommendations of women for doctoral process and daily life through this process?

\section{METHOD}

\section{Research Design}

This study aiming to analyze the doctoral process and lives of women doctoral students in terms of gender roles, was carried out as a qualitative interview-based research study. In this study, it is also aimed to find out the interaction between the student life and daily life of women doing doctorate in the context of the meaning they attribute to their experiences in a detailed way with positive and negative aspects.

\section{Participants}

The participants of the study were chosen through criterion sampling one of the purposeful sampling methods. Within purposeful sampling, the researcher works actively in choosing the most effective sample for determining all possible situations of a special group and answering the research question in order to reveal the information-rich conditions regarding the research question (Devers \& Frankel, 2000; Marshall, 1996; Neuman, 2007). The criteria in sampling were determined as doing doctorate in Çukurova University and being woman. Through qualitative studies, it is recommended that the number of individuals will be included in the sample should not be over 10 (Yıldırım \& Şimşek, 2008). In this regard, the participants of the study were limited to 10 women doctoral students. The age range was between $25-$ 
Table 1. Personal information about the participants

\begin{tabular}{lclllc}
\hline Participant & Age & Job & Program & Marital status & Number of children \\
\hline P1 & 25 & Teacher & G\&C & Single & - \\
P2 & - & Teacher & G\&C & Married & Single (engaged) \\
P3 & 31 & Res. Assist. & G\&C & Married & - \\
P4 & 30 & Res. Assist. & G\&C & Married & 1 \\
P5 & 30 & Res. Assist. & C\&I & Single (engaged) & - \\
P6 & 31 & Res. Assist. & C\&I & Single & - \\
P7 & 28 & Res. Assist. & G\&C & Single & - \\
P8 & 31 & Teacher & C\&I & Married & - \\
P9 & 33 & Teacher & C\&I & Single & 1 \\
P10 & 28 & Not working & C\&I & & - \\
\hline
\end{tabular}

*G\&C: Guidance and Counselling, C\&I: Curriculum and Instruction

33 years and 6 of them were single and 4 participants were married. Some of the participants were working as academicians ( 5 research assistants) as well and 4 of them were teachers and one participant was not working. The participants were doing their doctorate at Guidance and Counseling and Curriculum and Instruction programs.

The properties of the participants are also shown on Table 1.

\section{Data Collection}

In order to collect the data, a semi-structured interview form was structured by the researchers and asked for expert opinions. The experts were 5 instructors working at Curriculum and Instruction department of Çukurova University. In the first part of this form, there were questions concerning the personal information of participants (age, job, number of children, etc.). Following these, there were questions regarding how being a woman effects the doctoral process negatively or positively; the effects of doctoral process on the daily life; the reasons for doing doctorate; their reflections on the viewpoints of neighborhood regarding their doctoral studies; the recommendations for doctoral process and daily life through this process. The interviews were conducted in the researchers' or the participants' offices which lasted between 15 and 20 minutes. The interviews conducted were recorded by a tape recorder in order to prevent any data loss. All interviews were recorded not to allow any data loss.

\section{Data Analysis}

The data obtained from interviews were handled with content analysis approach. After the transcription of the interviews, the analysis was conducted using Nvivo 10 program. On the purpose of providing the reliability and validity for data analysis, two researchers coded together while the third researcher conducted the analysis alone. For the compatibility percentage of codes in two separate analyses, the reliability coefficient generated by Miles \& Huberman (1994) was used and the inter-coder reliability was found to be.89. Upon reaching an agreement on the discussed codes and themes, the last shape of the analysis was given. Through the study,
P abbreviation was used for participants (P1, P2, etc...). The findings were provided with many quotations from the interviews with the aim of increasing the objectivity within the study.

\section{FINDINGS}

\section{The Daily Activities of Women Doctoral Students}

Firstly, the participants were asked about their daily activities they carried out within doctoral process to reveal their daily routine to better understand the mutual effects of being a woman and doing doctorate. The findings were presented in Figure 1.

As it is indicated in Figure 1, making time for herself $(f=8)$ was the most mentioned theme by participants concerning daily activities. Besides, there were also themes such as working responsibilities $(f=7)$, doctoral studies $(f=6)$ and domestic responsibilities $(f=5)$. In the context of daily activities participants mostly carried out, there were work overload $(f=7)$, making time for housework $(f=4)$ and sparing time for assignments $(f=3)$. Regarding making time for housework statement, P5 explained her own situation as:

I can only spare 5-6 hours for the house apart from that. I mean at the house, there are works illegally assigned to women. That is, cooking or tidying up a day in our life is like this. (P5)

\section{The Effects of Being a Woman on Doctoral Process}

At the result of the content analysis conducted, the effects of being a woman on doctoral process were grouped as contributions and negative effects. The contributions of being a woman to doctoral process were presented on Figure $2 \mathrm{a}$.

As it is seen on Figure 2a, the views of participants were gathered under the themes the attitudes of instructors and advisors $(f=5)$, the personal skills being advanced $(f=3)$ and the effects on academic studies $(f=3)$. Through the contributions of being woman to doctoral process, participants most frequently mentioned the positive effects on the attitudes of instructors and advisor. They also indicated the positive effects on the personal skills' being advanced and academic 


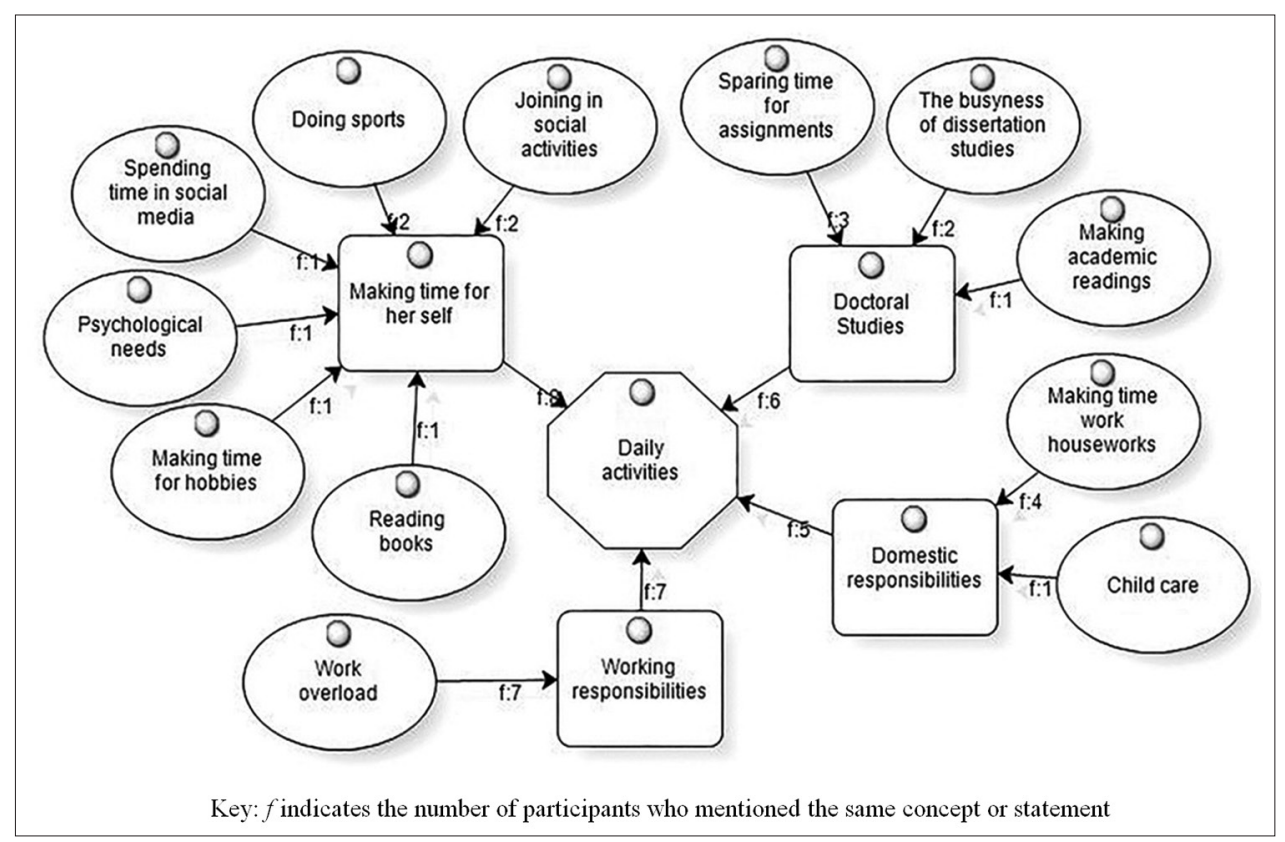

Figure 1. The views of doctoral students about their daily activities

studies. Some of the views of the participants were presented below:

Fairly, I didn't think anything like that in this department. I did not feel anything about being woman or man in terms of instructors. On the contrary, most instructors have something I mean supporting women. That is they should get education, make a career. I see this with most of our instructors. So I did not see that much negative attitude. (P1)

Being a woman that is, as I said maybe while I'm trying to do many things together I can think faster I improved myself for being able to do more than one thing at the same time. (P5)

The negative effects of being a woman on doctoral process were shown on Figure $2 b$.

It is seen on Figure 2b, within the negative effects of being a woman on doctoral process, mostly views regarding pregnancy and giving birth $(f=8)$ theme were mentioned. Besides, the effects of having children $(f=7)$ and difficulties due to expectations of society $(f=7)$ themes were emphasized. One of the participants stated:

For instance, she will experience problem due to lack of position. Another male colleague got a position and he was advantageous. He did not experience such a delay. This is very upsetting. One feels really aggrieved. (P3)

\section{The Effects of Doing Doctorate on Daily Lives of Women}

In the interviews, the positive and negative effects of doing doctorate on their daily lives were asked and findings were shown on Figure 3a.

As it is clear on Figure 3a, through the explanations of participants regarding the contributions of doing doctorate to their lives, mostly the views under social development $(f=16)$ theme were given place. The other opinions of women doctoral students were gathered under development in the study field $(f=9)$, personal development $(f=8)$, emotional develop- ment $(f=4)$ and developing the community $(f=2)$ themes. P8 mentioned about being respected by the society as:

It is weird but sometimes I feel that people respect for my doing doctorate not me. In the region I'm working most of the executives consist of people not much democratic, politically chosen, possessing an attitude of mind I find outdated. I feel even this group respects me for doing doctorate. (P8)

Findings concerning the negative effects of doctorate on women's daily lives were presented on Figure $3 \mathrm{~b}$.

It is seen on Figure 3b, the mostly emphasized themes in the context of negative effects of doctorate on daily lives regarding gender were psychological state $(f=8)$ and not being able spare time for oneself $(f=7)$. Besides, there were also other themes: the effect on home and family relationships $(f=4)$, having difficulty in planning the future $(f=3)$ and physical problems $(f=2)$. The statement of $\mathrm{P} 8$ was about the negative effect of doctorate process related to her marriage:

It had negative effects on my life in terms of marriage. In fact, doctorate was an excuse for me not to marry. In this point, I might have caused the people around me had a negative attitude for my doctoral process. (P8)

\section{The Reflections of Women Doctoral Students Regarding Neighborhood Reactions to their Doctoral Studies}

The participants were also asked about the viewpoints of neighborhood regarding women doctoral students and the findings were shown on Figure 4.

Regarding the reactions of neighborhood related to the women doctoral students there were mostly positive reactions $(f=15)$. Through this point, that there were also negative reactions $(f=5)$ was mentioned. Within the positive reactions by neighborhood the most frequent view was being appreciated $(f=7)$. One of the participants stated:

I am mostly appreciated. people know how much doctorate is difficult even they are not that concerned probably they 


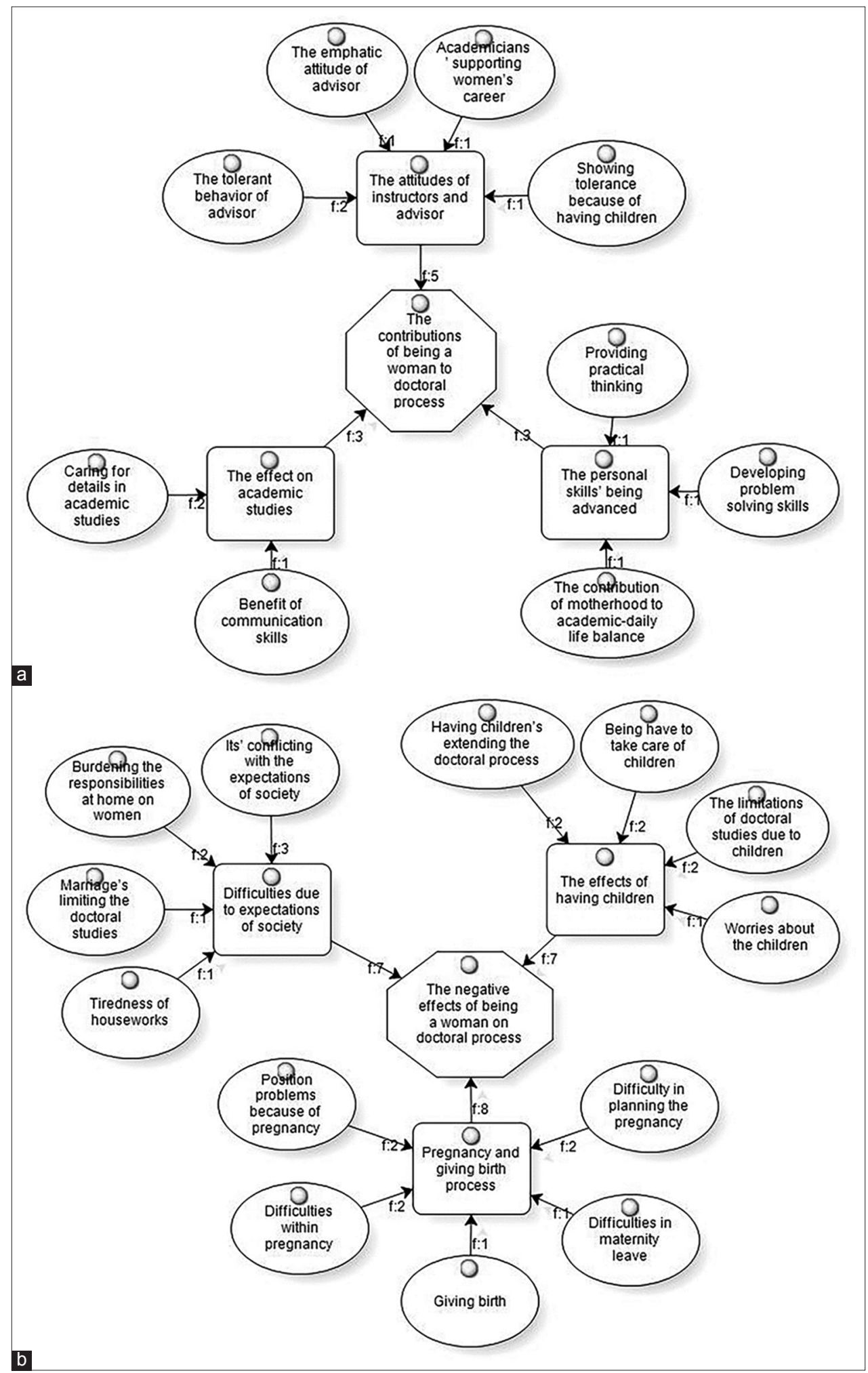

Figure 2. (a) The views about the contributions of being a woman to doctoral process (b) The views about the negative effects of being a woman on doctoral process

hear about it. In this respect, they know I put effort, do extra work for something and they appreciate this. (P3)

\section{The Recommendations of Women for Doctoral Process and DailyLife}

The recommendations of participants regarding the problems encountered through doctoral process and in their daily lives in terms of gender roles were gathered under the themes shown on Figure 5.

It is observed on Figure 5 that the most frequently mentioned themes within recommendations were changing perception towards gender roles $(f=11)$, the privileges regarding birth process $(f=6)$, having support mechanisms $(f=5)$, doing planning $(f=4)$ and arrangements for academic studies $(f=2)$. Regarding this P10 explained her views as: 


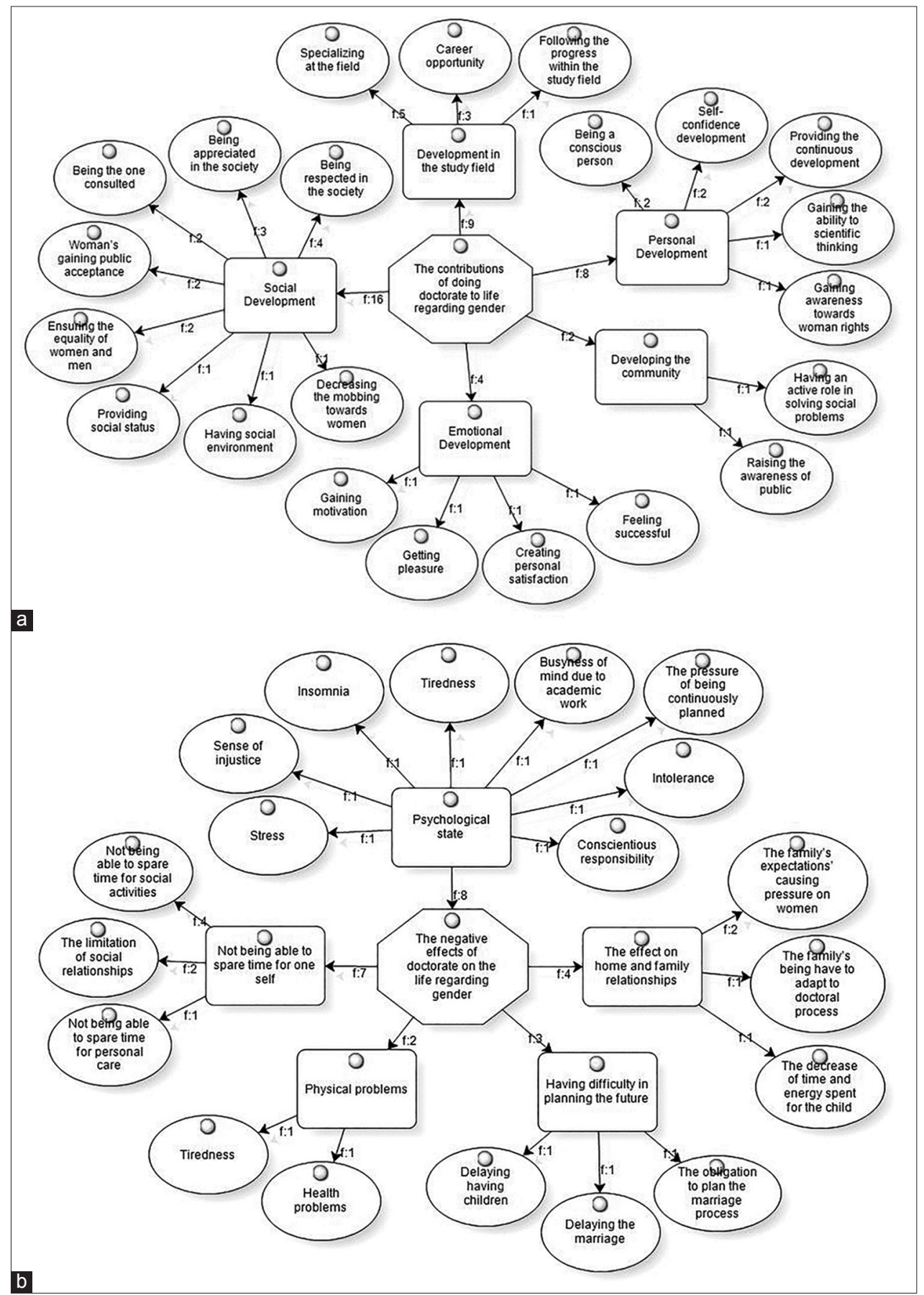

Figure 3. (a) The views about the contributions of doing doctorate to life regarding gender (b) The views about negative effects of doctorate on the life regarding gender

I think that the gender roles could be formed by primary education and so as individuals raised having a family in which modern perspective is taken, the free thought is emphasized, there is the sense of responsibility could form a more understanding society as individuals conscious and gained awareness and individuals living in such a society could encounter less problems regarding gender roles. (P10)

\section{DISCUSSION}

According to the findings of the study, being a woman influences both positively and negatively the doctoral study.
Participants mentioned 11 positive; 22 negative effects while answering this question. When the adverse effects of being a woman on doctoral study was analyzed, it was seen that participants most frequently addressed the negative effects of pregnancy and giving birth process, expectations of society and having children. As these points mentioned by participants were looked through, it could be easily seen that the fundamental factor having adverse effect on women's doctoral process was traditional gender roles. The participants mostly complained about the negative effects of their motherhood and housework duties attributed to them traditionally. This point is very clear in Maher, Ford and Thompson's 


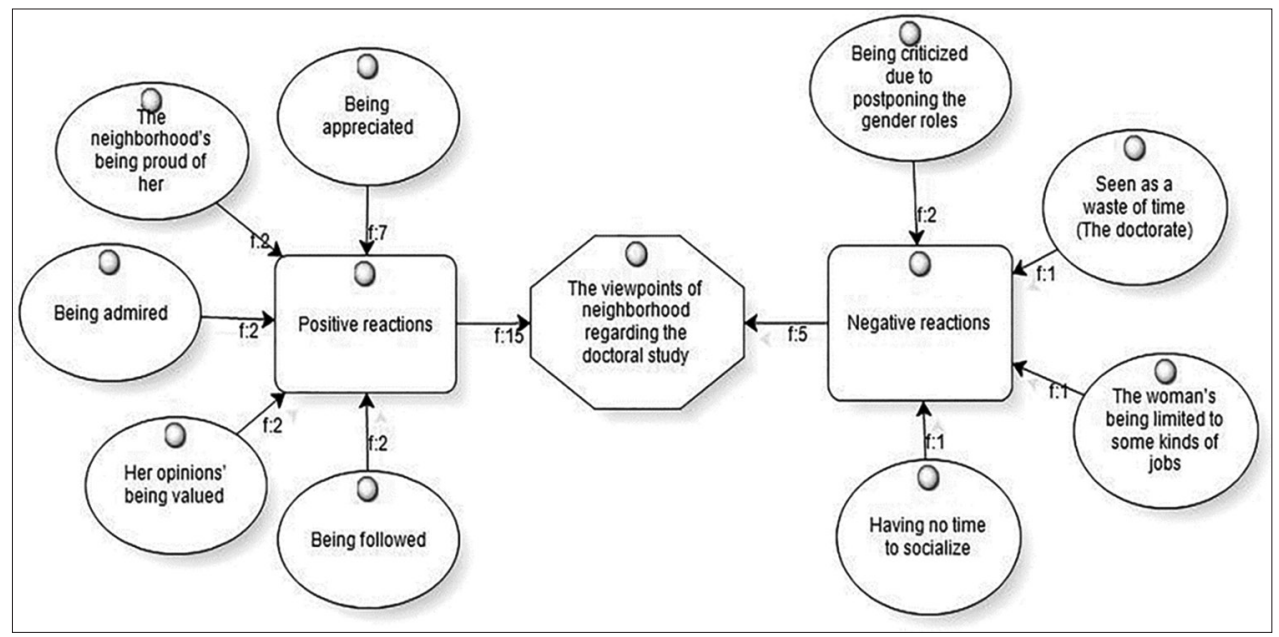

Figure 4. Viewpoints of neighborhood regarding the women doctoral students

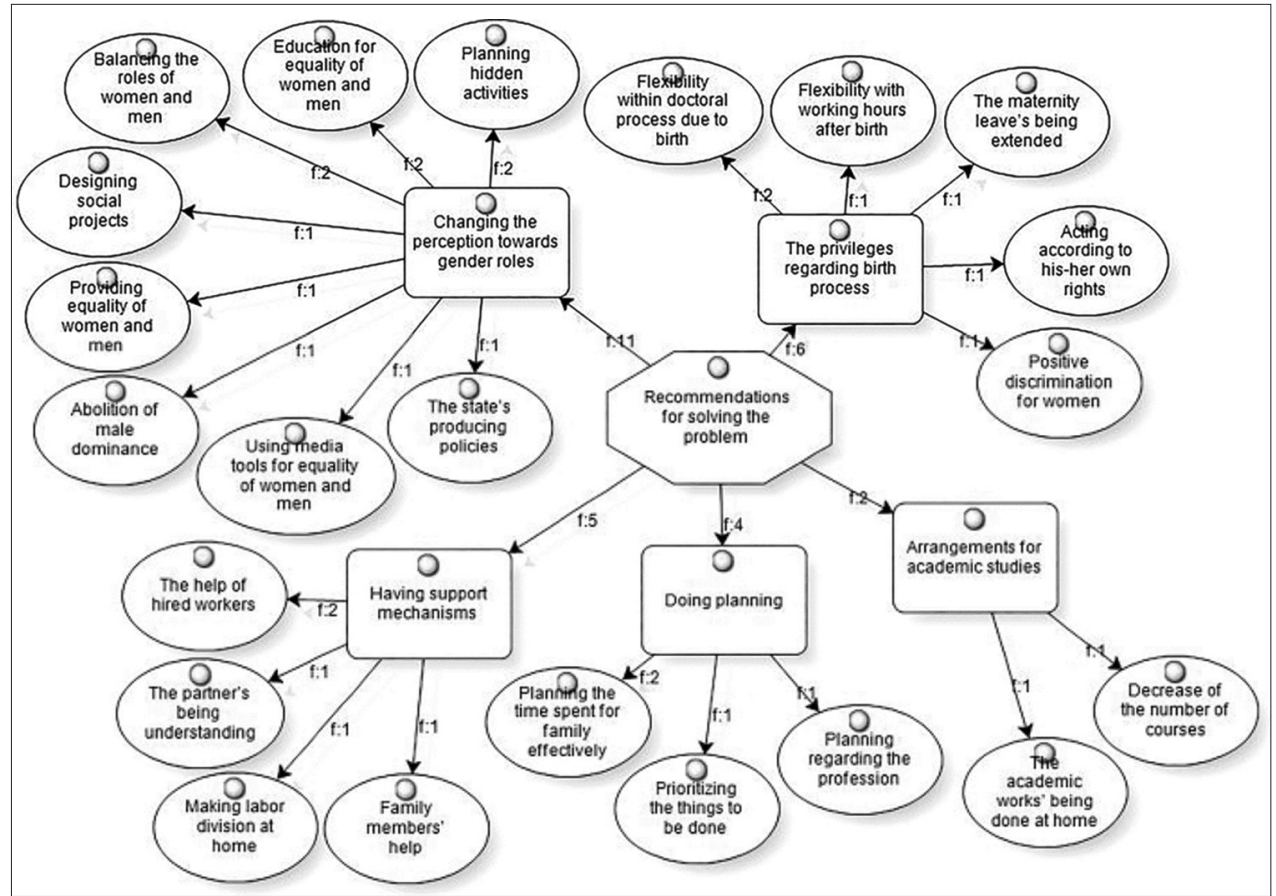

Figure 5. The recommendations for solving the problem in doctoral process

(2004) explanations that students, whether male or female, face with marriage and family problems through doctoral process frequently feel pressure. However, they emphasized that the possibility of women's, typically carrying more responsibility regarding house and child care, being effected by the problems encountered through these topics is higher than their men counterparts. When it is considered that nearly all the women participated in the study were teachers or research assistants; the responsibilities in business life were also added on the responsibilities related to house and family. This was mostly emphasized by both married and single participants which could be interpreted as a natural expectation coming along with traditional gender roles. Therefore, based on these multiple tasks, responsibilities and expectations encountered, it could be said that being a woman also brings about a set of disadvantages within doctoral process. Indeed, it is found out that the matters most complained about resulted from having multi tasks and responsibilities also in the study conducted by Başarır and Sarı (2015) with women academicians. It could be asserted that these multidimensional tasks create pressure and stress on women doctoral students. Just as in our study, it is emphasized that women in doctoral programs live more stress than men through related studies as well (Kurtz-Costes, Helmke, \& Ülkü-Steiner, 2006; Ülkü-Steiner, Kurtz-Costes, \& Kinlaw, 2000).

Participants of this study mostly mentioned the positive attitudes of advisors, their tolerant behaviors related to their being woman contributing to students' doctoral processes. Very similarly Kurtz-Costes, Helmke and Ülkü-Steiner (2006) also emphasize the importance of advisors' supporting behaviors. Participants of their study stated that supportive behaviors of the advisor helped to alleviate some of the stress caused by the conflict they felt between their personal and academic lives desired an advisor who facilitated their professional development, who took interest in them and their work, who was considerate of their time and personal 
lives and who helped to keep them on track. It was also put forward in Maher, Ford and Thompson's (2004) study, one of the fundamental factors facilitate to complete the doctorate on time is a helpful advisor. According to Smith (1995) the good relationship that a student has with an advisor is undoubtedly one of the most critical factors in a doctoral student's progress.

In the interviews, while explaining the contributions of doing doctorate on their daily lives, participants mostly mentioned various good feelings under the theme of social development. Within social development theme, participants stated that doing doctorate raised woman's place and status (respect) in the society. On the other hand, another contribution group might be handled within mutual interaction with social development was gathered under personal development theme. Here, features such as self-confidence, awareness, and continuous development were mostly indicated. The viewpoints of neighborhood regarding the women doctoral students could also be thought as a factor causing these features participants expressed. When the viewpoints of neighborhood regarding them were asked to participants, it was seen that they mostly mentioned positive reactions such as being appreciated. Being appreciated, being admired are significant factors through individual's developing positive attitude regarding him/her, and increasing self-respect. Self-respect is the admiration situation arises from individual's approving the self-concept s/he reached as a result of self-evaluation (Dilek \& Aksoy, 2013). The chance of individual's developing a positive attitude towards his/her own identity increases as much as they believe in people in neighborhood have positive ideas about themselves. With this regard, even they talked about some negative things explaining the reflections of doctorate on daily life, it could be asserted that doing doctorate is a factor increasing women doctoral students' self-respect, self-confidence.

On the other hand, when the negative effects of doing doctorate on women's daily lives were analyzed, it was observed that participants most frequently addressed psychological factors such as stress, insomnia, sense of injustice, tiredness; lack of time for personal care, social relationships and activities; negative effects on house and family life; difficulties in planning the future. These findings are consistent with the results within the literature and show that women doctoral students need more support through their educational process. Women doctoral students stating similar problems in the studies within literature as well, put emphasis on the importance of facilitating support by the advisor and family. For instance, the ones completed the doctoral process on time, without any extension among women participated in the study by Maher, Ford and Thompson (2004) were the ones having more close family support; while the others completed doctoral process late much more stressed child-care responsibilities and marital problems or other family-related obstacles. Beyond this, also in Kurtz-Costes, Helmke and Ülkü-Steiner's (2006) study it was found out that through doctoral process there was excessive stress having too much to do without sufficient time to accomplish all that was required and having little free time for oneself or one's family was also seen as stressful. In this sense, it is becoming evident that the support from advisor, family and close neighborhood for women doctoral students being at a level facilitating the doctoral process stressful by nature is crucial.

\section{CONCLUSION AND IMPLICATIONS}

Consequently, it is obvious that even though doing a doctorate has some advantages such as having a status, being respected, increasing self-development there are many adverse effects and conflicts for women due to their endeavor to balance academic and social life. The gender roles they are expected to fulfill push them for working more and also cause their being neglected within the academic life. As Lynch (2008) puts forward they suffer from the balancing between academic and domestic life and therefore experience maternal invisibility in academic processes while also use the academic invisibility within the family life. What they need is to have the respect for their success but also to have some flexibility regarding the difficulties arose from gender roles and also they need to be supported to feel the equality with men in every life step. Through these findings, a few suggestions could be asserted:

- Similar studies can be conducted with women doctoral students in different universities and departments to capture the whole picture,

- Some other quantitative (questionnaires, scales, etc.) and qualitative (long term observations as in ethnographic or other cultural studies) data collection methods could be used.

- The doctoral process should be scheduled in a more flexible way.

- The women doctoral students should obtain enough support from both academic authorities and the society's awareness regarding women's new position should be raised.

\section{REFERENCES}

Arat, Y. (2000). From Emancipation to liberation: the changing role of women in Turkey's public realm. Journal of International Affairs, 54 (1), 107-123.

Başarır, F. \& Sarı, M. (2015). Kadın akademisyenlerin 'kadın akademisyen olma' ya ilişkin algılarının metaforlar yoluyla incelenmesi (The analysis of women academicians' perceptions regarding "being woman academician” via metaphors). Yüksekögretim ve Bilim Dergisi, $5(1), 41-51$.

Devers, K. J. \& Frankel, R. M. (2000). Study design in qualitative research -2 : sampling and data collection strategies. Education for health, 13 (2), 263 - 271.

Dilek, H.\& Aksoy, A. B. (2013). Ergenlerin Benlik Sayg1s1 ile Anne-Babalarının Benlik Saygısı Arasındaki İlişkinin Incelenmesi (Analysis of relation between adolescents' self-respect and parents' self-respect). Ahi Evran Üniversitesi Kırşehir Eğitim Fakültesi Dergisi, 14 (3), 95-109.

Dinç Kahraman, S. (2010). Kadınların toplumsal cinsiyet eşitsizliğine yönelik görüşlerinin belirlenmesi (Determination of women's views regarding gender inequality). 
Dokuz Eylül Üniversitesi Hemșirelik Yüksekokulu Elektronik Dergisi, 3 (1), 30-35.

Duruoğlu, T. (2007). Emek piyasasında cinsiyetçi ücret ayrımı: Bursa organize sanayi bölgesinde bir araştırma (Sexist wage discrimination in labour market: A study in Bursa organized industrial site). Iletişim Kuram ve Araştırma Dergisi, 24, 61-67.

Elg, U. \& Jonnergård, K. (2003). The inclusion of female PhD students in academia: A case study of a Swedish university. Gender, Work and Organization, 10 (2), 154-174.

Ergöl, Ş., Koç., G., Eroğlu, K., \& Taşkın, L. (2012). Türkiye'de kadın araştırma görevlilerinin ev ve iş yaşamlarında karşılaştıkları güçlükler (Encountered difficulties of female research assistants at domestic and business life in turkey). Yüksekögrretim ve Bilim Dergisi, 2 (1), 43-49.

Fox, M. F. (2004). Women in scientific fields: Doctoral education and academic careers. Paper presented at the Workshop on Women's Advancement, American Political Science Association, Washington DC.

General Directorate on the Status of Women (GDSW). (2015). Türkiye'de kadın (Woman in Turkey). Retrieved October 20, 2015 from http://kadininstatusu.aile.gov.tr/ uygulamalar/turkiyede-kadin.

İnand1, Y. \& Tunç, B. (2012). Kadın öğretmenlerin kariyer engelleri ile iş doyum düzeyleri arasındaki ilişki (The relation between women teachers' career obstacles and job satisfaction levels). Eğitim Bilimleri Araştırmaları Dergisi, 2 (2), 203-222.

Kurtz-Costes, B., Helmke, L. A., \& Ülkü-Steiner, B. (2006). Gender and doctoral studies: The perceptions of $\mathrm{Ph} . \mathrm{D}$. students in an American university. Gender and Education, 18 (2), 137-155.

Leonard, D. (2001). A woman's guide to doctoral studies. Philadelphia: Open University.

Lynch, K. (2008). Gender roles and the American academe: A case study of graduate student mothers. Gender and Education, 20 (6), 585-605.

Maher, M. A., Ford, M., E., \& Thompson, C. M. (2004). Degree progress of women doctoral students: Factors that constrain, facilitate, and differentiate. The Review of Higher Education, 27 (3), 385-408.

Margolis, E. \& Romero, M. (1998). 'The department is very male, very white, very old, and very Conservative': The functioning of the hidden curriculum in graduate sociology departments. Harvard Educational Review, 68, 1-32.

Marshall, M. N. (1996). Sampling for qualitative research. Family Practice Oxford University Press, 13 (6), 522 - 525.

Miles, M. B. \& Huberman, A. M. (1994). Qualitative data analysis $\left(2^{\text {nd }}\right.$ ed.). Thousand Oaks, CA: Sage Publications.
Moyer, A., Salovey, P., \& Casey-Cannon, S. (1999). Challenges facing female doctoral students and recent graduates. Psychology of Women Quarterly, 23, 607-630.

National Science Foundation [NSF] Division of Science Resources Statistics (2004).Gender differences in the careers of academic scientists and engineers. Arlington: VA (NSF 04-323).

Neuman, W. L. (2007). Toplumsal araştırma yöntemleri, nitel ve nicel yaklaşımlar (Social research methods: Qualitative and quantitative approaches) (1. bs.). (Özge, S., Çev.). Ankara: Yayın Odası.

Onwuegbuzie, A. J., Rosli, R., Ingram, J. M., \& Frels, R. K. (2014). A Critical Dialectical Pluralistic Examination of the Lived Experience of Select Women Doctoral Students. The Qualitative Report, 19 (3), 1-35.

Patton, M. Q. (2002). Qualitative research \& evaluation methods ( $3^{\text {rd }}$ ed.). London: Sage Publications.

Raddon, A. (2002). Mothers in the academy: positioned and positioning within discourses of the 'successful academic' and the 'good mother'. Studies in Higher Education, 27, 387-403.

Smith, B. (1995). Hidden rules, secret agendas: Challenges facing contemporary women doctoral students. Paper presented at the Annual Meeting of the American Educational Research Association.

Sönmez, V. ve Alacapınar, F. G. (2011). Örneklendirilmiş bilimsel araştırma yöntemleri (Illustrated research methods) (1. bs). Ankara: Anı Yayınc1l1k.

Thomas S. P., Drake-Clark, D., Grasso, M., \& Banta, T. (2014). Enhancing doctoral completion in women: evidence from a qualitative study of a unique federally funded program. NASPA Journal about Women in Higher Education, 7 (1), 73-95.

Turkish Statistical Institute [TSI], (2015). Higher education Statistics 2013-2014. Retrieved on September 14, 2015 from http://www.tuik.gov.tr

Ülkü-Steiner, B., Kurtz-Costes, B., \& Kinlaw, C. R. (2000). Doctoral student experiences in male dominated and gender balanced graduate programs. Journal of Educational Psychology, 92, 296-307.

Wall, S. (2008). Of heads and hearts: Women in doctoral education at a Canadian university. Women's Studies International Forum, 31 (3), 219-28.

World Economic Forum (2017). The Global Gender Gap Report. Retrieved on January 15, 2018 from http://www3. weforum.org/docs/WEF_GGGR 2017.pdf.

Yıldırım, A. \& Şimşek, H. (2008). Sosyal bilimlerde nitel araştırma yöntemleri (Qualitative research methods in social sciences) (7. bs.). Ankara: Seçkin Yayıncılı. 